\title{
DEPICTING THE ITALO-AUSTRALIAN MIGRANT EXPERIENCE DOWN UNDER: IMAGES OF ESTRANGEMENT IN THE CINEMA OF GIORGIO MANGIAMELE
}

\section{Raffaele Lampugnani}

\begin{abstract}
Giorgio Mangiamele is widely regarded as the most significant first-generation Italo-Australian filmmaker of the post-war period. Indeed, as many critics have affirmed, Mangiamele's films of the fifties and sixties are fundamental for an accurate reading of Australian cinema in terms of its multiple representations of the non-Anglo Celtic migrant'. Yet, in spite of Giorgio Mangiamele's innovative contribution and efforts and in spite of his attempts to be accepted into Australian mainstream cinema by adopting English dialogue and Australian characters in many of his films, he remained marginalised as an ethnic filmmaker, achieving recognition and some financial support from Film Victoria only towards the end of the nineties. As was revealed clearly on many occasions before his death, Mangiamele deeply felt this lack of success and the constant rejection by the Anglo-Australian establishment. This study argues that Mangiamele's sentiment of repudiation and his sense of alienation are expressed in his films through images of closure, separation and distance and through situations depicting oppression and persecution, loss, derision and absence. Such iconic metaphors are apt not only to express the filmmaker's own perception but also the migrant's condition in Australia in the immediate post-war period.
\end{abstract}

Christian Metz, among his much debated remarks on the connection between psychoanalysis and cinema ${ }^{1}$, discusses the so-called 'nosographic approach' which 'would treat films as symptoms or as secondary manifestations that have been partially symptomatised, from which it is possible to "work back" to the neurosis of the filmSee Christian Metz, Le signifiant imaginaire. Psychanalyse et cinéma (Paris: Unions Général
d'Éditions, 1977). I will quote from the English version. 
maker...' and which would depend '...on two [correlated] postulates, that of the biographical and that of the pathological...' (Metz, 1982: 25-26).

The method outlined by Metz is especially valid in the case of the films of Giorgio Mangiamele (1926-2001) who is now generally recognised as the most significant first-generation post-war ItaloAustralian filmmaker and, in the words of John Conomos, 'foundational' in any enquiry aimed at 'reading Australian cinema in terms of its multiple representations of the non-Anglo-Celtic migrant since the 1920s' (1992:12). Such a 'nosographic' approach would enable critical analysis to move beyond the customary reading, or the mere categorising of Mangiamele's early work on the basis of migrant themes, without lessening the importance of the migrant experience depicted which is closely interconnected with the psychological aspect. As I have argued elsewhere (Lampugnani 2002: 17), in spite of the numerous recent tributes, and renewed critical work, there have been no in-depth analyses of Mangiamele's films either as artistic artefacts or as a reflection of his own personal experience since most critical efforts have attempted to periodise Mangiamele's production, placing it mainly in the post-war Italian Neo-realist tradition or in the context of migrant contribution ${ }^{1}$.

Whilst it is important to analyse these aspects, it is crucial for a 'nosographic' reading to also view Mangiamele's work in the light of his life-long struggle to be accepted by an industry that was notoriously antagonistic to what it perceived as 'ethnic'. Indeed, in spite of Giorgio Mangiamele's 'pioneering efforts' (Cutts, 1992: 17) and his attempts to be accepted into Australian mainstream cinema through commendable professional efforts and by adopting English dialogue and Australian characters in most of his films, he remained

\footnotetext{
Gaetano Rando, who is perhaps the most notable critic of Italo-Australian artistic production, assumes this position in his socio-historical study" Narrating the Italian Experience'. He states: 'Although [Mangiamele's] role in the emerging Australian film industry has been a relatively minor one, his is the only Italian name included in John Baxter's fundamental work on Australian cinema' (Castles 1992: 199). A similar position is held in Rando's latest book Emigrazione e letteratura: il caso italoaustraliano (Cosenza: Pellegrini Editore, 2004).
} 
marginalised as an outdated ethnic filmmaker by mainstream contemporaries ${ }^{1}$, achieving recognition only towards the end of the nineties. It is this feeling of rejection, isolation and banishment which permeates his work and reveals itself as a kind of fixated neurotic motif in opposition to other more optimistic images of hope. As critic Graeme Cutts pertinently remarks, Mangiamele was surprisingly precocious in his depiction of the Australian environment. ${ }^{2}$ And certainly his films are a close reflection of his unique life experiences as a migrant: the experience of a highly motivated, highly educated person, yearning to be accepted and integrated into mainstream society. If, on the one hand, Mangiamele shared the Italian migrant experience in his desire to be accepted and in his resourcefulness and resolve to succeed with few means, on the other, he was perhaps atypical as a migrant of the post-war generation, in that he was erudite and very sensitive to rejection. Mangiamele deeply felt this lack of success and the constant rejection by the Anglo-Australian establishment as is revealed clearly in the last interview granted before his death:

There was a lot of jealousy and envy... No, I did not feel like an Australian filmmaker. I was not accepted as an Aussie filmmaker because I was a migrant with an accent. I became an Australian citizen soon after I came to Australia. But this piece of paper makes little or no

\footnotetext{
1 Nigel Buesst, filmmaker contemporary to Mangiamele, rationalises this marginalisation on personal and stylistic grounds: 'On the question of Giorgio and why he didn't get more support from fellow filmmakers, first and foremost he favoured a romantic neo-realist style that seemed a bit old-fashioned to the young Turks of Lygon Street who had embraced the New Wave. Secondly he was very strong-willed as to how things should be and you wouldn't make much headway in changing his mind.' See Jake Wilson 'Carlton + Godard = Cinema: An Interview with Nigel Buesst' Senses of the Cinema July 2003, online at http://www.sensesofcinema.com/contents/03/27/carlton_plus_godard.html (accessed on 26 January 2005).

2 In his introduction to the Mangiamele Retrospective (Australian Centre for the Moving Image 20-22 January 2003) 'Some notes on the films of Giorgio Mangiamele', Graeme Cutts judges Mangiamele's early work as: '[a] very incredible work for a person, who basically had just stepped off a boat at Victoria Docks, Port Melbourne, and within a fairly short time started to make a very interesting and astute comment about what he found and observed'. This text is now available online in Inner Sense at http://www.innersense.com.au/mif./ mangiamele_notes.html_(accessed on 26 January 2005).
} 
difference to racist attitudes [...] I found that Australia was unexpectedly xenophobic, even if some Australians deny this and even if, although belatedly, some have called me the father of ethnic minority cinema in Australia. (Ditessa, 2001: 80)

The feeling of rejection, which is indeed very intense and expressed as a tangible pathological element in the early films, was conveyed vividly by the filmmaker as a feeling of persecution: 'I don't know what to say: blacklisted. I don't even know why [...] Silence, the silence of a tomb, typically Anglo-Saxon. They have ignored me for years. I was really trying to get some help' (Lampugnani 2002: 23).

This study proposes to re-examine Mangiamele's two complete "migrant" films, The Spag and Ninety-Nine Percent, and to reinterpret their images as a reflection of the filmmaker's state of mind. It is argued that Mangiamele's sentiment of repudiation and his sense of alienation are obsessively expressed in his films through images of closure, separation and distance and through situations depicting oppression and persecution, loss, derision and absence. But it is argued, in clear opposition to Christian Metz whose suggestion is that a nosographical or characteriological 'diagnosis', 'applied to persons (filmmakers)', would proclaim 'indifference to both the textual and to the social' (Metz, 27), that such iconic metaphors are apt not only to express the filmmaker's own perception but also the migrants' condition in Australia in the immediate post-war period.

\section{The Spag}

In The Spag (1961), Tony, a recently arrived young Italian boy tries to earn pocket money to help his widowed mother by selling and delivering newspapers in the streets of Carlton, an inner suburb of Melbourne. He befriends his landlord, Mr James (a shoe shop owner who gives him a pair of boots out of compassion), a greengrocer and other local residents, including John, a third generation Australian who helps him learn to speak, read and write English on the front steps of his cottage. Tony also befriends another Italian boy who too 
does newspaper rounds. When the latter invites him home to view television and learn to play Italian tunes on his guitar, Tony indicates that his deepest desire is to learn English and become well integrated and accepted in his adoptive country: he has left Italy and other things Italian behind and, whilst proud and affectionate toward his heritage, wishes to be part of his new environment. The two boys do in fact meet to attempt to play music on an oversize guitar for their age, but the best the two can produce is a stunted and distorted version of 'Twinkle, Twinkle Little Star' and not a traditional Italian tune (which nevertheless plays in the sound track as background music). Tony does yearn to listen to music but it is the idyllic, idealised kind of elitist classical music he hears from the window of Mr James' cottage: a music that in the context of the film is a signifier pointing to the world of the educated Australian hosts who are benevolent and tolerant. Tony can only stare through a massive wrought iron grille at the window and listen to the sound of his landlord playing on the piano. Representing the more educated and enlightened section of society, Mr James opens up briefly to the newcomer and shows him affection, drawing to one side the heavy grille on the window, but is only a temporary opening and the man soon closes it again, complaining about the heaviness and difficulty of moving such a weighty barrier.

Mr James' window is not the only image of obstruction and exclusion facing the protagonist of The Spag. Tony stares at his objects of desire through shop windows and draws images of coveted symbols such as the musical clef on panes of glass. His widowed mother is also shown predominantly as looking at her surroundings through her glass window. She is the most isolated character in the film, an iconic figure of grief clad in black and with her still young face obfuscated by moments of anguish - her only contact with her surroundings are through her son. And it is through these glass panes that she perceives the ominous signs of her son's death at the end of the film. But, whereas the better and more tolerant sections of society are only partly accessible to the migrant, the worst - represented here by the group of 'bodgies' and the vain young girls constantly roaming the streets and singling out, ridiculing, generally victimising the defenceless boy - 
are readily reachable. They teach the boy the worst about Australian society, including coarse behaviour and bad words which shock John, the boy's self-appointed English tutor. The bodgies are not aloof, negative elements of society but are ready to inflict physical harm (symbolically castrating) on anyone coming to the boy's aid.

It is not difficult to take the psychoanalytic inquiry further with The Spag through the reading of an oedipal situation even though this is not as clear-cut as in Mangiamele's other films. If the filmmaker (and spectator) is meant to identify with the child protagonist, how does he relate to his object of desire? Unlike Ninety-Nine Percent and Clay, the oedipal object of desire is not the mother or the female protagonist: in fact, the protagonist of The Spag resents what the mother stands for (returning to Italy). He yearns for acceptance by other male figures and in particular by John who stands as an adoptive father figure. It is in fact John who, at the end, carries the boy's lifeless body slumped in his arms in a visual arrangement strongly reminiscent of a religious composition. Film critic Raymond Bellour in 1979 offered a key interpretation of formations supporting Oedipus situations in cinema:

This configuration is founded on the relation of narcissistic doubling between man and woman... this doubling rules the two sexes' relations of desire. From it psychoanalysis is born - first Freudian, then Lacanian using the univocal model of Oedipus and castration to organise conflict and sexual difference around the restricted scene of the nuclear family. ${ }^{1}$

The object of desire is undoubtedly integration and acceptance into the Australian society at a time when it was strongly assimilationistic and where deep-seated racist attitudes could be vindicated by the very recent demise of the White Australia policy and still pervasive xenophobic attitudes. The sequence of images and situations in The

1 Raymond Bellour The Analysis of Film (Bloomington and Indianapolis: Indiana University Press, 2000), page 12, quoted in Vicky Lebleau Psychoanalysis and Cinema: The Play of Shadows (London and New York: Wallflower, 2001) 83. 
Spag suggests that the child protagonist is faced with multiple father figures who undoubtedly represent forms of access to Australian society: the older characters who are blind and ineffectual (as in the case of Mr James), the younger, fatherly, but almost effeminate John, who takes the protagonist under his protection and the frightful, and potentially castrating older male in the group of bodgies.

In the first confrontation between John and the bodgie, it is the latter who is stronger and grabs a broken bottle with the intention of doing physical harm to his opponent, thus emasculating him emotionally. It is John who is chastised by the police following the incident and not the bodgies. It is this same fear of being harmed that induces Tony to run away into the streets of Carlton and to his death at the end of the film. Poignantly, it is through his death that Tony connects fully with the adoptive father figure John and defeats the violent bodgie mannish figure whose aggressive cruelty is thus rendered ineffective.

But whilst the psychological dimension of the film with regards to the filmmaker's general obsessive longing for acceptance is discernible, a linear reading of filmic text is also complicated by intersecting religious images of charity, humility and sacrifice. The Christological image of the kind person tending to clean and protect the protagonist's feet with new boots will become a leitmotif in other films and the sequence of the dead Christ-like figure carried by John at the end of the film takes on the added pathos of Michelangelo's La Pietà, with all secondary characters forming a kind of naïve chorus of grieving figures in the background. It is quite likely that the character of John is an emblematic idealised figure, an imaginary signifier of goodness and acceptance that could not be found in the real-life experience of the filmmaker. Such was in fact Mangiamele's opinion on society when the question was put to him in a recent interview:

From a sentimental point of view, and this is a personal thing, [I cherish the most] The Spag. It is not at the same level technically as the other films, but my heart is in that film. [...] There we are: the persecution felt by the child because of racism, etc. That's what I saw then. 
And that is what persists today, we are still there today. That woman who speaks out now [in Parliament] against migrants, and again against the Vietnamese, the Asians and all that. This is a mentality that is unchanging. Even the humanitarian, the priest, the philosopher, whoever he might be, he says nice things in public on humanity, but he is racist deep down, and on occasions the poor migrant suffers. ${ }^{1}$

So the film's text can be read on two levels: on the one hand the mimetic appraisal of the migrants' encounters with persecution, xenophobia or at best an apparent and superficial attitude of tolerance and, on the nosographical plane, the dream-like phantasy sequence of acceptance (and remorse) following the protagonist's death which may be identified with a conscious obsessive yearning for fulfilment on the biographical plane.

\section{Ninety-Nine Percent}

Defined as Mangiamele's 'only comedy' (Cutts 2003), Ninety-Nine Percent (1963) could only partly be regarded as humorous. The film tells the story of an Italian migrant widower who tries to make a living selling his wares to his compatriots 'much as he would in the streets of Naples'. As the author explains:

Sono tremendi i difetti, sono difetti dell'uomo ignorante, analfabeta. Conosce appena appena quattro parole d'inglese... e riesce a vivere in un modo o nell'altro come sarebbe vissuto a Napoli. È umano però: lui ha cercato di farsi una moglie per il bambino, per il proprio figlio perché quello rimpiange la madre eccetera. È un fatto umano. Lui ha un sacco di cose per incontrare

\footnotetext{
1 The reference to the Parliamentarian speaking against migration was probably directed at the One Nation party which was in the news at the time of the interview (Lampugnani 2002: 24).
} 
questa donna qua, la sposa, ... la tua nuova madre sta per venire e poi la cosa fallisce e lui è demoralizzato, vinto. ${ }^{1}$

The protagonist, Pino, is illiterate and scarcely able to help his son Peter with his basic education: he is also quite inept at household chores. The images of the family home and the silence or scant difficult verbal exchanges between father and son highlight a deeply felt absence - that of the mother. This situation is cause of much unhappiness for both the father who feels inadequate because he is letting down his son and for the child, Peter, who converts his unhappiness into aggressive behaviour towards the father, accusing him of being uneducated. At the suggestion of a neighbour, Pino seeks the help of a matrimonial agency primarily to provide a 'new mother' to his son, but, when presented with a photograph of a suitable candidate, Pino's facial expression and body language suggest a badly disguised desire for sexual self-fulfilment: he drools over the image with the comment: "Geez! She's a film star!" A slapstick comedy situation develops as Pino, a small, dark and stout aging man (stereotypically Southern Italian) makes plans to meet and hopefully arrange a marriage with a very tall, blond Nordic woman who is physically quite unlike him (and the obvious contrast will remind viewers of the long-standing White Australia policy at the time).

We laugh at the various comical situations, at Pino's initial naivety and pretentiousness (he lies about his wealth to ensure the contact is made with the beautiful girl). A thrifty person, Pino saves for the future by hiding money in shoe boxes, under the carpet or behind a picture frame; he pretends to have forgotten his glasses to hide his illiteracy and covers a rip in his trousers with his hand. To go to the matrimonial agency he dons a suit, tie and hat, puts a flower in his lapel, takes an umbrella as a walking stick and pretends to smoke cigars to give himself an air of importance. But, at the end of the film, the humour turns to emotions of compassion as he is rejected and ridiculed by both his would-be bride and the numerous bodgies in the area. It is generally accepted that Mangiamele is a 'visual' director

1 Interview tape-recorded on Friday, 25 October 1996. Raffaele Lampugnani’s archive. 
and again it is possible to gather these sentiments of empathy through visual signifiers and through absence or the images of empty spaces; voids, images of a missing presence (such as the photo or the deceased wife and mother staring from the wall). The film begins and ends with a slapstick confrontation between Pino and an emblematic figure of a tall, thin, drunken man dressed and moving about in a way reminiscent of Charles Chaplin. The physical contrast between the drunkard and Pino could not be greater: the short and stout Italian and the lanky Australian stand confronting each other as a Laurel and Hardy pair of comedians. But the encounter does not lead to communication: the drunken man shouts "You fat wog!" and other more incomprehensible abuse at the migrant whilst the latter also shouts back in his defence. Long shadows and contrast of light and darkness emphasise distance and empty spaces between characters. The same lack of real communication is shown by the teachers and headmaster at Peter's school. They speak in a composed and expressionless manner, using clichés and set phrases or, in the words Quentin Turnour, in 'somnambulant, monosyllabic exchanges' (Turnour 1997).

Images of separation, closure and alienation are not just visual in Ninety-Nine Percent but are also embedded in the dialogue and the characters' body language: set phrases and stock expressions of politeness are a means of maintaining aloofness and distance from other individuals. Mangiamele elucidates the intention of the simulated dialogues in the film as mimetic of a social attitude:

[...] Anomalous affections, individuals who cannot communicate with others, not even with one's own husband or wife... there lacks that in-depth feeling which we Latins have in relationships... From an emotional point of view, I missed this very much, because I am one who gives a lot, but I must also receive a lot. That's the fact. In other words, this society does not give a lot. It is full of smiles. It is all fake in order for people to live peacefully with one another. Courteous and cordial, but only on the surface. No in- 
depth relationships, especially at that time, as I remember it. Only now things are starting to change. (Lampugnani 2002: 19)

Geometric shapes in courtyards taken in long-shots from above suggest the portrayal of a regulated society, cold, structured and materialistic. The migrants in this society are at risk of also becoming materialistic, placing more emphasis on money than on sentiments: after a profitable sale, Pino rubs his hands in satisfaction and exclaims: 'Business! Business!' to which son Peter responds: 'All you care about is money!' The pettiness of this small-time immigrant businessman is emphasised in shots where he is dwarfed by huge posters lining the urban streetscape. These materialistic attitudes which contaminate every aspect of social life, self-interest and a less overt oedipal drive also dominate the impending marriage arrangements. Pino seeks to gain sexual gratification in the form of a highly attractive and desirable younger woman while Peter sees the arrival of a new mother as a solution to a highly undesirable family situation (and the substitution within the family environment of an unappreciated, ineffective father).

The materialistic, physical attitude extends to everyone in the story: the manager of the matrimonial agency, when contacting the would-be bride, asks: 'Miss Koska, would you be interested in ten thousand pounds worth of man?' Miss Anastasia Koska lives in a high-rise modern apartment and, on the day of their first meeting, Pino needs to be helped up the stairs by his son; he feels unable to walk through the door and instead 'penetrates' the room with a huge bouquet of flowers first. Only partial metonymic images of Miss Koska are shown: her ankles and knees, her blonde hair, the perfectly white skin on her neck and arms, the delicate manicured hands, suggesting femininity and sexuality ${ }^{1}$. As Peter gazes in through a pane of glass, actively

1 The choice of a Northern European blonde woman for this character is obviously linked to the long-standing White Australia policy and connected societal attitudes, as well as being necessary in the context to provide a stark contrast to Pino's physiognomy, but it may also have individual psychological motivations. As the filmmaker explained when asked why he chose Australia as a destination, '... [I chose Australia because] there are blonde women 
participating in the scene and eagerly anticipating the encounter, the camera focusses on the girl's perfect white teeth and mouth. Her attractive smile slowly disintegrates into a frown of mockery and becomes distorted in bouts of uncontrolled laughter. This metonymic signifier is no longer one of femininity but quickly becomes one of derision, racism and scorn. Alternating shots of laughter and the terrified faces of both Pino and Peter convert the comedy into a highly poignant situation of mutual rejection and defeat for the Italian migrants. Tear drops streak across the pane of glass through which we see an overwhelmed child, his dreams shattered. Laughter of derision echoes in the street as local youths ridicule the pair while a deeper, more sinister imaginary laughter emanates from masks nailed to the wall. The two main protagonists' grief contrasts with joyful sounds of children in the park and confetti carried by the wind from a nearby church touch Pino's face, marking the contrast between the newlyweds' happiness and their own alienation and sadness. The sense of estrangement is subsequently emphasised by shots of empty squares, rubble, and newspapers in the wind. A highly suggestive (sexual, but not exclusively so) image of an erect wood twig stuck into the centre of a circle of pebbles merges almost immediately with the image of a circle of teasing mischievous children surrounding a lonely individual (the drunkard) in isolation, alienated by all around him. Father and son do find comfort in each other's companionship and a new sense of solidarity at the end of the film, but this is in contrast with the renewed and heightened feeling of estrangement from the rest of society.

Our re-examination of the two complete films with a specific migrant theme has highlighted images of closure, isolation and distance and situations depicting oppression and persecution, loss, derision or lack and revealed an intense sentiment of societal alienation and rejection. This may be seen as an attempt to portray both the general Italian migrant experience in Australia in the early sixties and Mangiamele's

here. The ideal woman is blonde - I don't know why, I cannot explain it. There are probably psychological reasons linked to my childhood. Because there are very few blonde women in Sicily. This is one reason...' (Lampugnani 2002: 19). 
own obsessive conflict in his professional environment and his existential disquiet.

Past criticism is somewhat divided on the thematic evaluation of these early films: as mentioned above, most commentaries group them in a category of 'migrant films' and praise their neo-realist qualities ${ }^{1}$ whilst some critics, as in the case of Quentin Turnour, highlight the universality of the situations and issues portrayed:

[...] the model of 'multicultural' filmmaking should not be overstated. The single mother and son (as with the single father and son in Ninety-Nine Percent) are defined by their relationship with sympathetic (or belligerent) Anglo-Saxons, rather than within the mores of an ethnic sub-culture. Rather than sketch the cultural forms that constrain minority communities ... both films allegorise the universal tragedy of loneliness. (Turnour, 1997)

\footnotetext{
See for example Bill Matsoulis 'Giorgio Mangiamele' Innersense available at
} http://www.innersense.com.au/mif.mangiamele.html and Graeme Cutts, op. cit. 
Whilst Turnour's appraisal is sensitive and insightful, it is important to also acknowledge a pattern of continuity and progression which marks Mangiamele's work as a whole. Whereas the aspiration in The Spag is rather ill-defined and may be identified with a general yearning for acceptance and paternal protection, the object of desire in Ninety-Nine Percent takes on a more distinct allegorical feminine form which the film-maker, in a cited interview, explicitly though perhaps unconsciously, associated with Australia ${ }^{1}$. Both the imaginary feminine representation and the fulfilment of desire will become most vivid and reciprocal in the character of Margot in Mangiamele's film Clay (1965). In fact, in this his last feature film both the object of desire, psychological tensions and relationships become fully articulated and defined. Mangiamele's work has the complexity and depth which disallows a univocal reading and, given that the filmmaker has indicated a specific interest in psychoanalysis ${ }^{2}$, a 'nosographic' interpretation of his early films is particularly useful to an appreciation of his work as a whole.

(Monash University)

\section{References}

Castles, S. et al. $1992 \quad$ Australia's Italians: Culture and Community in a Changing Society. St.Leonards, NSW: Allen \& Unwin

Conomos, J. $1992 \quad$ Cultural Difference and Ethnicity in Australian Cinema, in Cinema Papers 90: 12.

Cutts, G. $\quad 1992 \quad$ Interview, in Cinema Papers 90: 17.

\footnotetext{
See the opinion expressed by Mangiamele quoted in note 8

"I studied Freud. Above all I studied the Theory of Dreams. I speak a little German, but I read it in Italian as La teoria dei sogni, even though it doesn't work today because of... Then there is Psychoanalysis, a powerful and frightful theory, but today it is a theory devoid of any sense, a little like religion which has gone out of fashion." (Lampugnani 2002: 23).
} 


\begin{tabular}{|c|c|c|}
\hline- & 2003 & $\begin{array}{l}\text { Some Notes on the Films of Giorgio } \\
\text { Mangiamele in Inner Sense: http: // } \\
\text { www. innersense. com. Au / mif / } \\
\text { mangiamele_notes. }\end{array}$ \\
\hline Ditessa, R. & 2001 & $\begin{array}{l}\text { Mangiamele's Last Interview, in } \\
\text { Italy Down Under No. 6, Spring : } 80 .\end{array}$ \\
\hline Lampugnani R. & 2002 & $\begin{array}{l}\text { Envisioning the Italian Migrant } \\
\text { Experience Down Under: Giorgio } \\
\text { Mangiamele, Poet of the Image, in } \\
\text { Italian Historical Society Journal } \\
\text { (January-June, Vol. 10, No 1): 16-24. }\end{array}$ \\
\hline Lebleau, V. & 2001 & $\begin{array}{l}\text { Psychoanalysis and Cinema: The } \\
\text { Play of Shadows. London and New } \\
\text { York: Wallflower }\end{array}$ \\
\hline Metz, C. & 1982 & $\begin{array}{l}\text { Psychoanalysis and Cinema: the } \\
\text { Imaginary Signifier, Celia Britton et } \\
\text { al. (trans.). London and Basingstoke: } \\
\text { The Macmillan Press. }\end{array}$ \\
\hline Rando, G. & 2004 & $\begin{array}{l}\text { Emigrazione e letteratura: il caso } \\
\text { italoaustraliano. Cosenza: Pellegrini } \\
\text { Editore }\end{array}$ \\
\hline Turnour, Q. & 1997 & $\begin{array}{l}\text { Giorgio Mangiamele, } \\
\text { Cinemateque } 9715 \text { October. }\end{array}$ \\
\hline Wilson, J. & 2003 & $\begin{array}{l}\text { Carlton + Godard = Cinema: An } \\
\text { Interview with Nigel Buesst, in } \\
\text { Senses of the Cinema July. }\end{array}$ \\
\hline
\end{tabular}

